\title{
Can Agroforestry Farmers Attain Sustainability? Case of Farmers in Selected Upland Farming Communities in the Philippines
}

\author{
Leila D. Landicho*, Josefina T. Dizon, Agnes C. Rola, Maria Ana T. Quimbo, \\ Rowena DT. Baconguis
}

University of the Philippines Los Baños, Philippines.

*Corresponding author e-mail: ldlandicho@gmail.com

\begin{abstract}
How to Cite: Landicho, L.D., Dizon, J.T., Rola, A.C., Quimbo, M.A.T., Baconguis, R.D.T. (2017). Can Agroforestry Farmers Attain Sustainability? Case of Farmers in Selected Upland Farming Communities in the Philippines, Int. J. Agr. Syst. 5(2): 101-119.
\end{abstract}

\begin{abstract}
This article is based on the study which investigated the socioeconomic and biophysical conditions of the upland farming communities in the Philippines; identified the development pathways that were undertaken by the upland farmers; and determined level of sustainability of the upland farming communities on the basis of their development pathways. This article argues that agroforestry farmers in upland farming communities in the Philippines can attain sustainability. This argument is based on the study conducted in the three pilot upland communities of the Conservation Farming Villages program in Albay, Ifugao and Negros Oriental, Philippines. From seven focus group discussions (FGDs) with at least 12 participants per FGD for a total of 147 farmers, and farm household survey of 230 upland farmers, research results indicate that agroforestry farmers in the three study sites were smallholders and were cultivating in areas with marginal conditions. There were five development pathways identified. These are monocropping in contour, multiple cropping in contour, agroforestry, agroforestry with non-farm activities, and multiple cropping/monocropping without contour. With the community capitals framework as the theoretical foundation, analysis indicated that the five development pathways contributed to a high level of social, human and political capitals having mean scores of 0.73, 0.55 and 0.54, respectively; a moderate level of physical, financial and natural capital, with mean scores of $0.23,0.20$ and 0.23 , respectively; and a very low level of cultural capital with mean score of -0.08. At the community level, on the other hand, research results revealed that the CFV sites in Ligao, Albay and La Libertad, Negros Oriental have almost similar contributions to the sustainability of the upland farming communities, while Alfonso Lista, Ifugao had the lowest. Thus, institutional arrangements with the farmers' association and the local government units also played a key role in the sustainability of the upland farming communities. These results imply the need for a holistic and collaborative engagement towards attaining sustainable upland farming communities.
\end{abstract}

Copyright () 2017 IJAS. All rights reserved.

\section{Keywords:}

Community capitals framework; contour; non-farm activities; conservation farming villages

\section{Introduction}

Sustainable development is enabling all people throughout the world to satisfy their basic needs and enjoy a better quality of life without compromising the quality of life of the future generations (Brundtland Commission, 1987). The government of Scotland has set out five principles of sustainable development, namely: living within environment 
units; ensuring a strong, healthy and just society; promoting good governance; using sound science responsibly; and achieving a sustainable economy (Pillai, 2010). To attain sustainable development, UNCED (1992) identified four goals which should be achieved. These are: (a) meeting the needs of tomorrow's generation through today's decisions; (b) balancing social, economic and environmental objectives which requires the application of people-centered approaches including local knowledge, ideas and values; (c) managing natural systems within their limits; and (d) focusing on development and not growth. These claims are supported by Bass et al. (1995) who argued that environmental sustainability, economic sustainability and social sustainability are the 44 main anchors of sustainable development.

One of the determinants of sustainable communities is having sustainable livelihoods. Chamber and Conway (1991) emphasized that livelihood comprises the capabilities, assets and activities required for a means of living. It is comprised of the assets (natural, physical, human, financial and social capital), the activities, and the access to these that together determine the living gained by the individual or a household. Scoones (1998) added that livelihood is sustainable when it can cope with and recover from stress and shocks, maintain its capabilities and assets while not undermining the natural resource base. Sustainable development can likewise be measured at the macro-level, particularly at the community-level. On the basis of the Brundtland Commission's definition of sustainable development, which is the ability of the community or society to satisfy the needs of the present without sacrificing the future generation, the stocks or assets of the community, therefore, define the sustainability of a particular community.

As Cochrane (2006) argued, capital is the material needed for the production of valuable goods and services and productive capital to satisfy needs. Thus, if capital stocks are not maintained, the flow of goods and services will decrease over time and intergenerational aspect of sustainability will not be met. Five important community capitals or assets include human capital, natural capital, social capital, physical capital and financial capital. Flora et al. (undated) noted the experiences of the Community Economic Development (CED) in measuring the sustainability of the communities on the basis of the seven community capitals. These include natural capital which is characterized with the air quality, land, water and water quality, natural resources, biodiversity and scenery; cultural capital which includes the values, heritage, recognition and celebration; human capital such as population, education, skills, health, creativity, youth and diverse groups; social capital which includes trust, norms of reciprocity, network structure, group membership, cooperation, common vision and goals, leadership, depersonalization of politics, acceptance of alternative views, and diverse representation; political capital, which includes level of community organization through the use of government, ability of government to garner resources for the community; financial capital including tax burden/savings, state and federal tax money, philanthropic donations, grants, contracts, regulatory exemption, investments, reallocation, loans and poverty rates; and, built capital such as housing, transportation infrastructure, telecommunication infrastructure and hardware, utilities and buildings.

This article highlights the level of sustainability of the selected upland farming communities based on the development pathways that they have undertaken. Development pathway is defined as "a common pattern of change in livelihood strategies, where livelihood 83 strategies are defined as the activities that generate the means of household survival" (Ellis, 2000 as cited by Pender, 2004). The pattern of change is associated with causal and conditioning 85 factors (Pender, 2004). Thus, development pathways are routes taken by the households through 86 resource 
allocation decisions in response to interventions (Rola, 2011). While the concept of development pathway may be akin to farming systems and livelihood strategies, they also touch and incorporate the non-farm and farm activities, and are dynamic since they refer to changes and not merely livelihood strategies pursued at a particular point in time.

Change in livelihood strategies or development pathways are all geared towards improving the environmental and economic dimensions of human development. For instance, de Janvry and Sadouilet (2001) noted four basic potential paths in Latin America. These include the agricultural path, multiple activity path, assistance path and exit path. There are farming communities that have also changed their pathway from farming to non-farm activities also termed as farm exit as those studied in Nepal. Bhandari (2013) argued that human, natural and social capitals have influenced the transition of livelihood strategies to farm exit. In some cases, policy reforms also help smallholder farmers make their way out of poverty. For instance, the liberalization of agricultural market in Vietnam has led to the shift from subsistence-oriented production to market-oriented production which has increased farmers' income and significantly reduced their poverty rate.

In Malawi, on the other hand, the reforms on the reduction of the protection of large estates have encouraged farmers to shift to the production of cash crops, particularly tobacco (World Development Report, 2008). In farming communities, therefore, the choice of development pathways is oftentimes geared towards the improvement of the economic status of the farmers.

\section{Materials and Method}

The study was conducted in the Conservation Farming Village (CFV) pilot communities in Ligao City, Albay; Alfonso Lista, Ifugao; and, La Libertad, Negros Oriental (Figure 1). The data were gathered using focus group discussions (FGDs), farm household survey, key informant interviews (KIIs), direct observation and secondary data gathering. The FGD was conducted in each of the villages with a total of 147 participants. Farm household survey involved a total of 230 farmer-respondents who were selected using random sampling. Descriptive statistics particularly percentages, frequency counts and weighted scores were used for the socioeconomic characteristics, biophysical conditions and structures and processes that prevail in the community. Thematic analysis was done for the data gathered from the FGDs. Corresponding indicators were identified for each of the seven community capitals, namely: social, human, political, physical, financial, natural, and cultural. The respondents scored each indicator under each capital 1 for improved; 0 for stable or no change; and -1 for declined. Mean score of each of the seven capitals was computed by summing the scores divided by the total number of respondents. The level of sustainability was determined using the following scales: -1.00 to -0.50 as very low; $0.51-0.00$ as low; $0.01-0.50$ as moderate; and 0.51 to 1.00 as high level. 


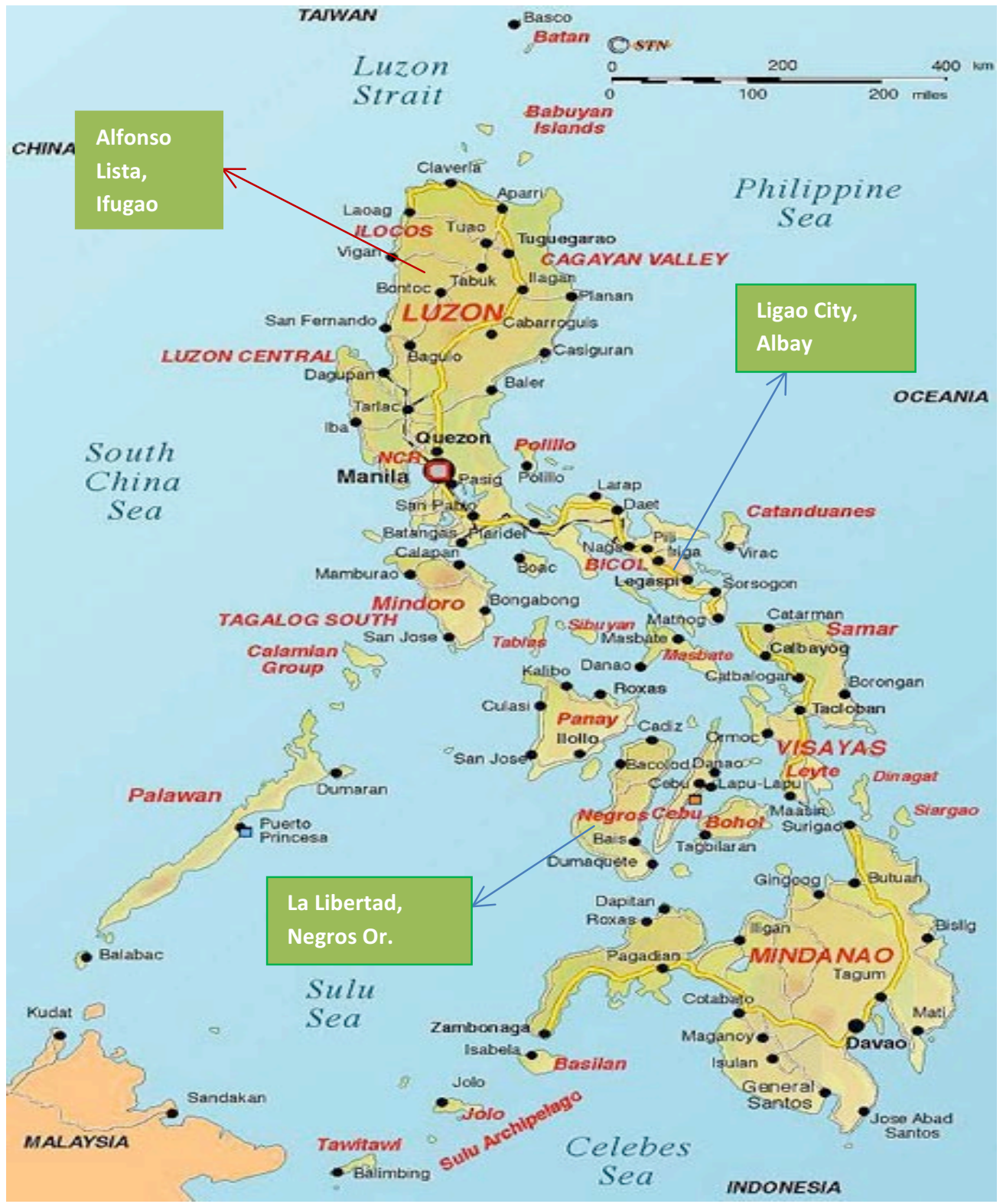

Figure 1. Philippine map showing the location of the study sites

\section{Results and Discussion}

\subsection{Socioeconomic and biophysical characteristics of the study sites}

The study sites represent the general conditions of the upland farming communities, with marginal conditions and in need of rehabilitation; and at the same time, offer the potentials of improving the farming systems for their agriculture-based economic development. Table 1 shows that the mean age of upland farmers is 54 . This finding suggests that they are still in their productive years. It was noted that farmers were as young as 22 years old and as old as 79 years, which indicates the interest of young generation to engage in farming, and the interest of older farmers to sustain their farm development activities. Almost all $(90 \%)$ of the farmers were married with a mean household size of five (5). This suggests the availability of family labor for farm development activities, and the opportunity of members to engage in non-farm related activities as sources of household income. Many $(42 \%)$ of the farmers have reached 
elementary education. Similar with previous studies (Visco et al., 2012; Landicho et al., 2015; Gutierrez, 2013), the rural farmers, in general, have limited opportunities to reach higher level of education. This could be brought about by their limited access to education facilities and opportunities, distance of upland communities to education facilities, and personal choice of the farmers.

All of the farmer-respondents were engaged in farming as their main source of livelihood, while there were still some $(9 \%)$ whose household members are engaged in off-farm activities and non-farm employment (40\%). These upland farmers are smallholders as their mean landholding is 1.5 hectares from which they derived an estimated mean annual income of Php20000. Despite the small landholding, most of the farmers owned the farms that they cultivate. This provides an opportunity of maximizing land use because they can decide about the crop species to be planted and the farming systems that would be employed.

Table 1. Socioeconomic characteristics of the farmer-respondents in the three study sites

\begin{tabular}{|c|c|c|c|}
\hline \multicolumn{2}{|c|}{ Socioeconomic Characteristics } & \multirow{2}{*}{$\begin{array}{c}\text { Frequency } \\
16\end{array}$} & \multirow{2}{*}{$\begin{array}{c}\text { Percentage } \\
7\end{array}$} \\
\hline Age (years) & $<30$ & & \\
\hline & $30-40$ & 54 & 23 \\
\hline & $41-50$ & 7 & 33 \\
\hline & $51-60$ & 55 & 24 \\
\hline & $>60$ & 28 & 12 \\
\hline & Mean & \multicolumn{2}{|c|}{54} \\
\hline \multirow[t]{4}{*}{ Civil status } & Single & 7 & 3 \\
\hline & Married & 208 & 90 \\
\hline & Separated & 0 & 0 \\
\hline & Widow/er & 15 & 7 \\
\hline \multirow{7}{*}{ Education } & No formal education & 1 & 0.4 \\
\hline & Elementary graduate & 97 & 42 \\
\hline & Elementary undergraduate & 52 & 23 \\
\hline & High school graduate & 41 & 17 \\
\hline & High school undergraduate & 27 & 12 \\
\hline & College graduate & 7 & 3 \\
\hline & College undergraduate & 5 & 0.6 \\
\hline \multirow[t]{4}{*}{ Household size } & $1-3$ & 48 & 21 \\
\hline & $4-6$ & 133 & 58 \\
\hline & $>6$ & 49 & 21 \\
\hline & Mean & \multicolumn{2}{|c|}{5} \\
\hline \multirow[t]{3}{*}{ Income sources } & Farming & 230 & 100 \\
\hline & Farming and off-farm & 21 & 9 \\
\hline & $\begin{array}{l}\text { Farming and non-farm } \\
\text { employment }\end{array}$ & 94 & 40 \\
\hline Estimated annual income & $<10000$ & 18 & 8 \\
\hline \multirow{3}{*}{ (Php) } & $10000-20000$ & 84 & 36 \\
\hline & $21000-30000$ & 2 & 1 \\
\hline & $31000-40000$ & 15 & 6 \\
\hline
\end{tabular}




\begin{tabular}{|c|c|c|c|}
\hline \multicolumn{2}{|c|}{ Socioeconomic Characteristics } & Frequency & Percentage \\
\hline & $41000-50000$ & 25 & 11 \\
\hline & $>50000$ & 75 & 32 \\
\hline & Mean & \multicolumn{2}{|c|}{20000} \\
\hline \multirow[t]{5}{*}{ Farm size (ha) } & $<1.0$ & 78 & 34 \\
\hline & $1.0-3.0$ & 14 & 61 \\
\hline & $3.1-5.0$ & 7 & 3 \\
\hline & $>5.0$ & 5 & 2 \\
\hline & Mean & \multicolumn{2}{|c|}{1.50} \\
\hline \multirow[t]{4}{*}{ Land tenure status } & Owned & 123 & 53 \\
\hline & Tenant & 77 & 35 \\
\hline & Rented/Leased & 5 & 2 \\
\hline & Public land & 25 & 10 \\
\hline
\end{tabular}

The general topography of the farms in the three study sites is rolling to steep slopes as shown in Table 2. This indicates a higher probability of soil erosion in these farmlands if certain soil and water conservation measures are absent. Ligao City and La Libertad have Type II climate which is characterized as having no dry season and the maximum rain period is from November to January. Areas having this type of climate are suitable for growing annual crops particularly vegetables and cereals considering the availability of rainfall throughout the year. On the other hand, Alfonso Lista belongs to Type III climate with dry periods for almost half of the year. Thus, the farmers that are highly dependent on rainfall may be constrained to produce waterrequiring crops particularly vegetables. Rainfall is an important biophysical factor in upland farming communities because agricultural production depends largely on it for irrigating the agricultural crops. In reality, the upland farms are generally inaccessible to irrigation system because of the geographical location. Except in La Libertad whose irrigation water for crops is sourced from springs, most of the farms being maintained by the farmer-respondents in Ligao City and Alfonso Lista are rainfed as reported by 39 per cent of the respondents. This finding suggests the vulnerability of the upland farming communities to climate change, particularly long dry spells.

Table 2. Biophysical characteristics of the upland farms in the study sites

\begin{tabular}{llcc}
\hline \multicolumn{1}{c}{ Biophysical Characteristics } & Frequency & Percentage \\
\hline Topography & Flat & 73 & 32 \\
& Rolling & 82 & 36 \\
\multirow{5}{*}{ Water source } & Steep & 74 & 32 \\
& Creek/River & 97 & 42 \\
& Spring & 11 & 5 \\
& Rainfed & 100 & 43 \\
& Irrigation & 8 & 3 \\
& Water pumps & 16 & 7 \\
\hline
\end{tabular}

\subsection{Development pathways undertaken by the upland farmers in 2011-2015}

Survey results showed that in 2011-2015, five development pathways have been undertaken by the upland farmers in the three study sites. These are as follows:

a. Agroforestry and non-farm activities. This pathway is described as the combined production of agricultural crops and woody perennials (i.e. fruit trees and forest trees) in the same unit of land, while other household members are engaged in nonfarm employment. This pathway covers other variants such as corn-based 
agroforestry with non-farm activities; rice-based agroforestry with non-farm activities; and, agroforestry with contour hedgerows and non-farm activities. This pathway is being practiced by a total of 97 farmer-respondents across the three study sites. An estimated mean annual income of Php178,118 was generated from this pathway.

b. Agroforestry. This pathway refers to the combined cultivation of agricultural crops and woody perennials in the same unit of land. It covers the variants of agroforestry which include corn-based agroforestry with contour hedgerows; agroforestry with contour hedgerows; and, rice-based agroforestry with contour hedgerows, which is being practiced by a total of 52 farmer-respondents. An estimated mean annual income of Php42,803 was derived from this pathway.

c. Monocropping in contour. This pathway is described as the cultivation of a single crop in a single unit of land/farm employing contour hedgerows as the soil and water conservation measures. This pathway covers variants such as corn monocropping, root crops monocropping, and rice monocropping all planted along the contour, which is being adopted by 32 farmer-respondents. An estimated mean annual income of Php12,994 was generated by this pathway across the three study sites.

d. Multiple cropping in contour. This pathway is characterized with the cultivation of two or more agricultural crops in the same unit of land and the sequence may either be relay cropping, crop rotation and intercropping. This pathway covers the different variants of multiple cropping, which include corn-based multiple cropping with contour hedgerows, and multiple cropping with hedgerows. This pathway has generated an estimated mean annual income of Php11,737, and is being practiced by a total of 26 farmer-respondents.

e. Multiple cropping/monocropping without contour. This pathway covers monocropping and multiple cropping without contour hedgerows, nor planting along the contour. This pathway is being practiced by a total of 23 farmerrespondents and has generated an estimated mean annual income of Php52,183.

\subsection{Outcomes of the development pathways on the community capitals}

The Community Capitals Framework, which is the theoretical foundations of this paper, highlights the seven community capitals as major measures of a sustainable community. These are the social capital, natural capital, physical capital, financial capital, human capital, political capital and the cultural capital. These seven capitals should be present in a community to enable the community achieve its sustainability. The status and the corresponding contributions of the development pathways on seven community capitals of the three study sites are discussed below. Table 3 shows that, overall, the five development pathways have contributed to a high level of social, human and political capitals across the study sites, with mean scores of $0.73,0.51$ and 0.55 , respectively. However, these pathways have contributed to a moderate level of natural, financial, and physical capitals, with mean scores of $0.39,0.20$ and 0.23 , respectively, and a very low level of cultural capital, having a mean score of -0.08 .

These results explain the immediate effects and contributions of the development pathways on the social, human and political capitals. For instance, the formation of CFV Farmers' Association and organizing group activities could have strengthened the community partnership from 2007 when the CFV program was implemented until the present. The training programs that have been organized by the CFV program and the local government units could have enhanced the human capital build-up of the farmers after attending a series of these training programs and cross-farm visits. The adoption 
of the development pathways could have led to the realization of the local government units to institute local policies that would promote agroforestry and conservation farming practices in the study sites. Thus, these findings suggest that the outcomes of the development pathways in these three capitals can be measured within five years.

On the other hand, the moderate level of community capitals indicates that it needs a longer time before a particular development pathway takes effect on capitals such as natural, financial, physical, and cultural capitals. For instance, a significant effect of the development pathways on the natural capital may not be immediate because soil rehabilitation is a long process. However, it should be noted that pathways 'monocropping in contour', 'multiple cropping in contour', 'agroforestry', and 'agroforestry with non-farm activities' have improved crop yield, and have improved soil condition because of the lesser occurrence of soil erosion. These are the direct outcomes of the development pathways which could later on help soil fertility restoration, in particular, and improve the natural capital, in general.

Similarly, it takes time before the farmers can accumulate significant financial and physical capitals, as these also depend on the level of the natural capital. When the natural capital has improved, farm productivity would also improve, which could lead to a higher farm income. Higher farm income would then contribute to the financial capital accumulation of the farmers, which would then enable them to build-up their physical capitals for a more efficient agricultural production.

Table 3. Mean score of the contributions of five development pathways on the status of community capitals in the three study sites

\begin{tabular}{lcccccc}
\hline \multirow{2}{*}{$\begin{array}{c}\text { COMMUNITY } \\
\text { CAPITALS }\end{array}$} & $\begin{array}{c}\text { Monocrop } \\
\text { ping in } \\
\text { contour }\end{array}$ & $\begin{array}{c}\text { Multiple } \\
\text { cropping in } \\
\text { contour }\end{array}$ & Agroforestry & $\begin{array}{c}\text { Agroforestry } \\
\text { +non-farm }\end{array}$ & $\begin{array}{c}\text { Monocropping } \\
\text { without } \\
\text { contour }\end{array}$ & TOTAL \\
\hline Social capital & 0.63 & 0.68 & 0.78 & $\mathbf{0 . 8 3}$ & 0.73 & 0.73 \\
Human capital & 0.43 & 0.56 & $\mathbf{0 . 5 8}$ & 0.50 & 0.49 & 0.51 \\
Natural capital & 0.25 & $\mathbf{0 . 4 7}$ & $\mathbf{0 . 4 7}$ & 0.32 & 0.42 & 0.39 \\
Financial capital & 0.23 & 0.08 & 0.13 & $\mathbf{0 . 2 8}$ & 0.24 & 0.20 \\
Physical capital & 0.18 & 0.21 & 0.29 & 0.17 & $\mathbf{0 . 3 5}$ & 0.23 \\
Cultural capital & -0.12 & -0.32 & -0.33 & $\mathbf{0 . 0 1}$ & -0.13 & -0.08 \\
Political capital & $\mathbf{0 . 8 3}$ & 0.79 & 0.53 & 0.20 & 0.42 & 0.55 \\
\hline
\end{tabular}

Specifically, the effects of the development pathways on the seven community capitals are as follows:

\section{Social capital}

Social capital is about the value of social networks, bonding similar people and bridging between diverse people (Dekker and Uslaner, 2001 in Claridge, 2004). There are two levels of social capital. The bonding social capital exists within a community which enables people to get by; and, the bridging social capital refers to the extracommunity networks that enable individuals of groups to tap outside sources of information, support and resources to be able to get ahead (Cramb, 2004). Among the indicators of social capital in this study ware the status of participation of the community members to various community activities, interaction and communication 
of the community members, and the community's partnership or linkage with organizations or agencies outside the community.

Survey results show that regardless of the type of the development pathways, the status of the social capital in the three study sites is high, having a mean score of 0.63 , $0.68,0.78,0.83$ and 0.73 for 'monocropping in contour'; 'multiple cropping in contour'; 'agroforestry'; 'agroforestry and non-farm activities'; and 'multiple cropping/ monocropping without contour', respectively (Table 4). The formation of the CFV Farmers' Association could have motivated the individual farmers to actively participate in the community activities and bayanihan or group activities, regardless of the type of development pathway that they choose. When the CFV program was implemented in the study sites, the formation of the CFV Farmers' Association was among the initial community activities. It is through these farmers' associations (FAs) where technical and financial assistance of the CFV program were coursed through during the project implementation. The formation of these FAs was also seen as an opportunity for an effective and efficient promotion of conservation farming, and as a mechanism and vehicle towards sustaining the project activities. Most of the farmerrespondents were natives of these communities, and therefore, their shared meanings and symbols facilitated their communication and interaction. Thus, social capital was high across the study sites.

Table 4. Mean scores of social capital indicators of farmers engaged in different development pathways

\begin{tabular}{lccccc}
\hline \multirow{2}{*}{$\begin{array}{c}\text { INDICATORS OF } \\
\text { SOCIAL CAPITAL }\end{array}$} & $\begin{array}{c}\text { Monocropping } \\
\text { in contour }\end{array}$ & $\begin{array}{c}\text { Multiple } \\
\text { cropping in } \\
\text { contour }\end{array}$ & Agroforestry & $\begin{array}{c}\text { Agroforestry } \\
\text { and non-farm } \\
\text { activities }\end{array}$ & $\begin{array}{c}\text { Monocropping } \\
\text { without contour }\end{array}$ \\
\cline { 2 - 6 } $\begin{array}{l}\text { Communication and } \\
\text { interaction of the } \\
\text { community members }\end{array}$ & 0.94 & 0.92 & 0.80 & 0.85 & 0.63 \\
\hline $\begin{array}{l}\text { Participation to the } \\
\text { community activities }\end{array}$ & 0.89 & 0.65 & 0.79 & 0.85 & 0.92 \\
such as bayanihan & 0.42 & 0.48 & 0.74 & 0.78 & 0.64 \\
\hline $\begin{array}{l}\text { Partnership with } \\
\text { external organizations }\end{array}$ & 2.25 & 2.06 & 2.33 & 2.49 & 2.19 \\
\hline TOTAL SCORE & $\mathbf{0 . 7 5}$ & $\mathbf{0 . 6 9}$ & $\mathbf{0 . 7 8}$ & $\mathbf{0 . 8 3}$ & $\mathbf{0 . 7 3}$ \\
\hline MEAN SCORE & & & & & \\
\hline
\end{tabular}

Their bridging social capital has also improved during and after the implementation of the CFV program. They have established partnership with the state colleges and universities such as Bicol University College of Agriculture and Forestry (BUCAF) for the study site in Ligao, Albay; Ifugao State University (IFSU) for the study site in Alfonso Lista, Ifugao; and Silliman University for the study site in La Libertad, Negros Oriental. The local government units in the three municipalities, particularly the Office of the Municipal Agriculturist also played an important role in their community development. These offices took charge in the field-level promotion of conservation farming practices in the three study sites through the CFV Program.

\section{Human capital}

Human capital is the stock of competencies, knowledge and personality attributes embodied in the ability to perform labor so as to produce economic value. The quality of manpower is very critical in agricultural production. In general, the farmers in the 
three study areas have improved their human capital based on the indicators, namely: training experiences in agricultural production and conservation farming; number of household members engaged in agricultural production; and, use of indigenous knowledge in farming. Results show that the farmers engaged in the pathways 'agroforestry', 'multiple cropping in contour' and 'agroforestry with non-farm activities' have the highest level of human capital as indicated by the mean score of $0.57,0.56$ and 0.50 , respectively (Table 5). From among the indicators of human capital, the five development pathways have contributed to improved knowledge and skills of the farmer-respondents in upland farming and conservation practices, with a mean score of 0.73 . This is attributed to the training courses and cross-farm visits that were organized by the CFV project and the local government units. The CFV Report (2011) highlights that the program has trained a total of 3,253 farmers in the three study sites which covered a total of 73 on-site and off-site training programs along the areas of agroforestry, soil and water conservation and planting stock production. Cross-farm visits have likewise been organized to enable the farmers see for themselves the workable and farmer-level agroforestry systems and technologies.

Table 5. Mean scores of human capital indicators of farmers engaged in different development pathways

\begin{tabular}{lccccc}
\hline \multirow{1}{*}{$\begin{array}{c}\text { INDICATORS OF } \\
\text { HUMAN CAPITAL }\end{array}$} & $\begin{array}{c}\text { Monocrop } \\
\text { ping in } \\
\text { contour }\end{array}$ & $\begin{array}{c}\text { Multiple } \\
\text { cropping in } \\
\text { contour }\end{array}$ & Agroforestry & $\begin{array}{c}\text { Agroforestry } \\
\text { and non-farm } \\
\text { activities }\end{array}$ & $\begin{array}{c}\text { Multiple cropping } \\
\text { and monocropping } \\
\text { without contour }\end{array}$ \\
\hline $\begin{array}{l}\text { Local knowledge in } \\
\text { farming }\end{array}$ & 0.63 & 0.51 & 0.69 & 0.27 & 0.37 \\
\hline $\begin{array}{l}\text { Training and skills in } \\
\text { agriculture and NRM }\end{array}$ & 0.80 & 0.85 & 0.72 & 0.68 & 0.65 \\
\hline $\begin{array}{l}\text { Access to NRM-related } \\
\text { information }\end{array}$ & 0.69 & 0.26 & 0.54 & 0.54 & 0.40 \\
\hline $\begin{array}{l}\text { Sources of agriculture- } \\
\text { related information }\end{array}$ & 0.71 & 0.41 & 0.67 & 0.54 & 0.57 \\
\hline $\begin{array}{l}\text { Number of household } \\
\text { members trained in } \\
\text { farming and NRM }\end{array}$ & 0.00 & 0.78 & 0.46 & 0.55 & 0.48 \\
\hline $\begin{array}{l}\text { Number of household } \\
\text { members involved in } \\
\text { farming }\end{array}$ & 0.00 & 0.40 & 0.46 & 0.41 & 0.39 \\
\hline $\begin{array}{l}\text { Knowledge about existing } \\
\text { policies in NRM and }\end{array}$ & 0.17 & 0.69 & 0.29 & 0.52 & 0.33 \\
\hline agriculture & 3.00 & 3.91 & 4.00 & 3.52 & 3.47 \\
\hline TOTAL SCORE & $\mathbf{0 . 4 3}$ & $\mathbf{0 . 5 6}$ & $\mathbf{0 . 5 7}$ & $\mathbf{0 . 5 0}$ & $\mathbf{0 . 4 9}$ \\
\hline MEAN SCORE & & & & \\
\hline
\end{tabular}

It may be noted, though, that while there are those engaged in the pathway 'cropping without contour', they may have participated in the on-site training courses being members of the CFV Farmers' Association. Meanwhile, the pathways 'agroforestry with non-farm activities', 'monocropping in contour', and 'multiple cropping in contour' have moderate levels of human capital. The farm households with non-farm activities may have limited time and opportunity to join the training courses because of their other engagement. 


\section{Natural capital}

The land/farms being cultivated by the farmers; the rivers, creeks and springs, forest and other natural resources that abound in the community, which are utilized by the farmers for their livelihood, are all considered as their natural capital. Table 6 indicates that except for pathway 'monocropping in contour' with a low level of natural capital (0.28), the rest of the development pathways have contributed to a moderate level of natural capital in the three study sites. It may be noted that pathways 'agroforestry' and 'multiple cropping in contour' have the highest mean score of 0.47. This finding suggests that the contour hedgerows in the rolling and steep slopes of the farms have become an effective means of improving crop yield and productivity because of the controlled soil erosion. The interaction of the different components in an agroforestry system could have also contributed to the rehabilitation the soil, particularly the use of nitrogen-fixing species as hedgerows such as Calliandra (Calliandra calothyrsus), Flemengia, (Flemengia macrophylla) and Rensonii (Desmodium cinereum). The moderate contribution of contour hedgerows and agroforestry and other development pathways employing contour hedgerows to the natural capital could be because the soils are still in the early stages of restoration and rehabilitation.

Table 6. Mean scores of natural capital indicators of farmers engaged in different development pathways

\begin{tabular}{lccccc}
\hline \multirow{2}{*}{$\begin{array}{c}\text { INDICATORS OF } \\
\text { NATURAL } \\
\text { CAPITAL }\end{array}$} & $\begin{array}{c}\text { Monocropping } \\
\text { in contour }\end{array}$ & $\begin{array}{c}\text { Multiple } \\
\text { cropping in } \\
\text { contour }\end{array}$ & Agroforestry & $\begin{array}{c}\text { Agroforestry } \\
\text { and non-farm } \\
\text { activities }\end{array}$ & $\begin{array}{c}\text { Multiple cropping } \\
\text { and monocropping } \\
\text { without contour }\end{array}$ \\
\hline Soil fertility & 0.73 & 0.46 & 0.18 & 0.11 & 0.14 \\
\hline Farm productivity & -0.15 & 0.41 & 0.26 & 0.19 & 0.45 \\
\hline $\begin{array}{l}\text { Occurrence of soil } \\
\text { erosion }\end{array}$ & 0.75 & 0.81 & 0.85 & 0.60 & 0.66 \\
\hline $\begin{array}{l}\text { Access to water } \\
\text { resources }\end{array}$ & 0.075 & 0.52 & 0.56 & 0.44 & 0.33 \\
\hline $\begin{array}{l}\text { Access to forest } \\
\text { resources }\end{array}$ & 0.00 & 0.15 & 0.48 & 0.25 & 0.30 \\
\hline TOTAL SCORE & 1.40 & 2.35 & 2.33 & 1.59 & 1.88 \\
\hline MEAN SCORE & $\mathbf{0 . 2 8}$ & $\mathbf{0 . 4 7}$ & $\mathbf{0 . 4 7}$ & $\mathbf{0 . 3 2}$ & $\mathbf{0 . 3 8}$ \\
\hline
\end{tabular}

The decrease in the occurrence of soil erosion is the most significant contribution of the four development pathways that were undertaken by the farmer-respondents across the study sites, with a mean score of 0.72 . Contour hedgerow intercropping or alley cropping in a sloping land is an agroforestry practice of planting leguminous plants on the contour to provide green leaf manure to fertilize annual crops and serve as barrier to soil loss (Garrity et al., 1993). Contour hedgerow systems using nitrogen fixing trees have been widely viewed and promoted as important components of soil conservation in Southeast Asia to minimize soil erosion, restore soil fertility, and subsequently improve crop productivity (Mercado et al., 2000).

\section{Physical capital}

Physical capital refers to the basic infrastructure and producer goods needed to support livelihood (DFID, 2000). At the farmer level, the farmers own farm tools that are used in their agricultural production. These were either acquired by the farmers or given by the CFV program. At the community level, on the other hand, the infrastructure facilities were lacking and need improvement. Table 7 highlights that the 
physical capital of the farmers engaged in each of the five development pathways are in moderate level. The pathway 'no contour' has the highest mean score of 0.30 , and 'agroforestry with non-farm activities' has the lowest mean score of 0.11 . From the six indicators, availability of market outlets for the products has been the greatest contribution of the development pathways, having a mean score of 0.53 . Specifically, pathways 'agroforestry with non-farm activities' and 'cropping without contour' have mean scores of 0.22 which indicates a moderate level of physical capital. This is so because the farmers engaged in the former may have access to post-harvest facilities because of the relatively higher income derived from the non-farm activities. The farmers engaged in the latter, on the other hand, could be more accessible to facilities such as irrigation system that is usually installed in relatively flat or lower elevation areas.

Table 7. Mean scores of physical capital indicators of farmers engaged in different development pathways

\begin{tabular}{lccccc}
\hline \multirow{2}{*}{$\begin{array}{c}\text { INDICATORS OF } \\
\text { PHYSICAL CAPITAL }\end{array}$} & $\begin{array}{c}\text { Monocrop } \\
\text { ping in } \\
\text { contour }\end{array}$ & $\begin{array}{c}\text { Multiple } \\
\text { cropping in } \\
\text { contour }\end{array}$ & Agroforestry & $\begin{array}{c}\text { Agroforestry } \\
\text { and non-farm } \\
\text { activities }\end{array}$ & $\begin{array}{c}\text { Multiple cropping } \\
\text { and monocropping } \\
\text { without contour }\end{array}$ \\
\hline $\begin{array}{l}\text { Farm tools and } \\
\text { equipment }\end{array}$ & 0.10 & 0.16 & 0.12 & 0.04 & 0.25 \\
\hline $\begin{array}{l}\text { Post-harvest tools and } \\
\text { facilities }\end{array}$ & -0.02 & 0.00 & -0.003 & -0.03 & -0.07 \\
\hline $\begin{array}{l}\text { Transportation facilities } \\
\text { for agricultural products }\end{array}$ & 0.48 & 0.42 & 0.44 & 0.34 & 0.51 \\
\hline Farm-to-market road & 0.15 & 0.27 & 0.05 & -0.04 & 0.27 \\
\hline $\begin{array}{l}\text { Availability of market } \\
\text { outlets }\end{array}$ & 0.47 & 0.54 & 0.52 & 0.52 & 0.60 \\
\hline $\begin{array}{l}\text { Distance of market } \\
\text { outlets from the } \\
\text { community }\end{array}$ & 0.18 & -0.125 & -0.11 & -0.18 & 0.24 \\
\hline \multicolumn{1}{c}{ TOTAL SCORE } & 1.36 & 1.10 & 1.01 & 0.65 & 1.80 \\
\hline \multicolumn{1}{c}{ MEAN SCORE } & $\mathbf{0 . 2 3}$ & $\mathbf{0 . 2 1}$ & $\mathbf{0 . 1 7}$ & $\mathbf{0 . 1 1}$ & $\mathbf{0 . 3 0}$ \\
\hline
\end{tabular}

Overall, however, their physical facilities could be low because of the general conditions of the community, particularly the poor farm-to-market road especially in La Libertad and Alfonso Lista. Therefore, the accumulation of physical capitals is not solely the result of the adoption of a particular development pathway, but also of the general community conditions and infrastructure. There were no post-harvest facilities found in the three study sites. Except in Ligao City, the farm-to-market roads in the two CFV areas were in poor condition. While there were market outlets within the barangay, these poor road conditions hamper the livelihood activities of the upland farming communities particularly in marketing their agricultural products outside the barangay.

\section{Financial capital}

Financial capital is defined by DFID (2000) as the financial resources that people use to achieve their livelihood objectives. Financial capital, therefore, is a very critical asset in farming or agricultural production as this becomes the source of farmers' capacity to buy farm inputs (e.g. seeds, fertilizers, pesticides and others) and hire farm labor in case family labor is not available. Financial capital also provides buffer of the farm households in case agricultural production fails brought about by pest infestation, 
natural calamities such as drought and typhoons, and market failure; or in case of emergency in the farm households.

The five development pathways have similar outcomes on the financial capital of the farmer-respondents in the three study sites (Table 8). From the nine indicators, improved farm income has been the significant contribution of the development pathways, with a mean score of 0.72 . Overall, however, the status of financial capital status is considered as low having a mean score of $0.23,0.08,0.12,0.28$, and 0.24 for 'monocropping in contour'; 'multiple cropping in contour';' agroforestry'; 'agroforestry with non-farm' and 'cropping without contour', respectively. It may also be noted, however, that from among the development pathways 'agroforestry with non-farm' has the highest mean primarily because of the contributions of the non-farm activities/employment to the household income. On the other hand, 'agroforestry' has the lowest mean score most likely because of the type of crop and farm size. In general, the farmer-respondents engaged in this pathway cultivate mostly root crops, vegetables and corn, which are intended for home consumption, thus, limited income is derived from this pathway.

Table 8. Mean scores of financial capital indicators of farmers engaged in different development pathways

\begin{tabular}{lccccc}
\hline \multirow{2}{*}{$\begin{array}{l}\text { INDICATORS OF } \\
\text { FINANCIAL CAPITAL }\end{array}$} & $\begin{array}{c}\text { Monocrop } \\
\text { ping in } \\
\text { contour }\end{array}$ & $\begin{array}{c}\text { Multiple } \\
\text { cropping in } \\
\text { contour }\end{array}$ & Agroforestry & $\begin{array}{c}\text { Agroforestry } \\
\text { and non-farm } \\
\text { activities }\end{array}$ & $\begin{array}{c}\text { Multiple cropping } \\
\text { or monocropping } \\
\text { without contour }\end{array}$ \\
\hline $\begin{array}{l}\text { Number of sources of } \\
\text { household income }\end{array}$ & 0.57 & 0.38 & 0.38 & 0.38 & 0.20 \\
\hline Income from farming & 0.67 & 0.50 & 0.38 & 0.36 & 0.31 \\
\hline $\begin{array}{l}\text { Income from non-farm } \\
\text { activities }\end{array}$ & -0.05 & 0.00 & -0.11 & 0.53 & 0.09 \\
\hline $\begin{array}{l}\text { Income from off-farm } \\
\text { activities }\end{array}$ & 0.60 & -0.26 & -0.07 & 0.10 & 0.26 \\
\hline Access to credit services & 0.60 & -0.10 & 0.19 & 0.21 & 0.28 \\
\hline $\begin{array}{l}\text { Presence of } \\
\text { multipurpose coop }\end{array}$ & -0.075 & -0.17 & 0.15 & 0.30 & 0.59 \\
\hline $\begin{array}{l}\text { Access to multipurpose } \\
\text { coop }\end{array}$ & -0.25 & -0.12 & -0.10 & 0.27 & 0.42 \\
\hline Household savings & -0.037 & 0.025 & -0.37 & 0.02 & -0.27 \\
\hline Land ownership & 0.075 & 0.47 & 0.67 & 0.34 & 0.28 \\
\hline \multicolumn{1}{c}{ TOTAL SCORE } & 2.02 & 0.72 & 1.12 & 2.51 & 2.16 \\
\hline \multicolumn{1}{c}{ MEAN SCORE } & $\mathbf{0 . 2 3}$ & $\mathbf{0 . 0 8}$ & $\mathbf{0 . 1 2}$ & $\mathbf{0 . 2 8}$ & $\mathbf{0 . 2 4}$ \\
\hline
\end{tabular}

It was also observed that none of them have household savings. They argued that the income that they earn from farming and other income sources are used for household expenditure. Thus, having a bank account and savings has not become their priority. From among the three study sites, Alfonso Lista had the highest financial accumulation of 0.23 . This could be because the farmers had been engaged in corn production (for feeds), which is intended primarily for market. However, Ligao and La Libertad had a mean score of 0.055 and -0.07 , respectively, because most of the farmers had been growing crops for their home consumption. Crops are only sold in the market when there are surpluses. 
Marketing is a secondary consideration in upland farming among the majority of the farmer-respondents. As such, the farmers tend to produce crops that are mostly staple food of the family such as upland rice, corn, and root crops. They have not been engaged in high value crop and fruit tree production. This can be explained by the socioeconomic and biophysical factors. For instance, most of the farmer-respondents are smallholder farmers who have limited landholding, and whose farmlands are considered as marginal areas with steep slopes, rainfall dependent and with lower soil fertility level. Thus, engaging in agricultural production of livelihood activity with higher input requirements have become a constraint.

\section{Cultural capital}

Cultural capital consists of symbols, language, festivals, celebrations and events (Jacobs, 2011). It is a shared identity that exists in a community. Among the seven community capitals, cultural capital is invisible and non-material, but provides the basic foundation of the community. The social relationship, symbols shared by the community, including the norms and values of the community members are founded on their cultural capital. Among the indicators of cultural capital are the indigenous knowledge systems that are being utilized and observed by the community in upland farming; and the local traditions that are being celebrated in the community were among the three indicators of cultural capital in this study.

Results show a very low level of cultural capital for all pathways (Table 9). This finding indicates that regardless of the development pathways, the level of cultural capital in the three study sites is generally low. This may not be an effect of the pathways, but more of the community practices and traditions. For instance, the pathway 'multiple cropping with hedgerows' is dominant in Ligao City where many of the farmers have also reported to have been observing rituals during planting season. On the other hand, there is little observance of the cultural beliefs in La Libertad and Alfonso Lista. In general, however, the cultural disintegration in the Asian rural societies is much observed in the recent years (Tolentino et al., 2012). This is brought about by the environmental change, modernization and technological advancement.

Table 9. Mean scores of cultural capital indicators of farmers engaged in different development pathways

\begin{tabular}{|c|c|c|c|c|c|}
\hline \multirow[b]{2}{*}{$\begin{array}{c}\text { INDICATORS OF } \\
\text { CULTURAL CAPITAL }\end{array}$} & \multicolumn{5}{|c|}{ MEAN SCORES OFDEVELOPMENT PATHWAYS } \\
\hline & $\begin{array}{l}\text { Monocrop } \\
\text { ping in } \\
\text { contour }\end{array}$ & $\begin{array}{l}\text { Multiple } \\
\text { cropping in } \\
\text { contour }\end{array}$ & Agroforestry & $\begin{array}{l}\text { Agroforestry } \\
\text { and non-farm } \\
\text { activities }\end{array}$ & $\begin{array}{l}\text { Multiple cropping } \\
\text { and monocropping } \\
\text { without contour }\end{array}$ \\
\hline $\begin{array}{l}\text { Practice of local } \\
\text { traditions in the } \\
\text { community }\end{array}$ & 0.15 & -0.44 & 0.26 & -0.28 & -0.31 \\
\hline $\begin{array}{l}\text { Cultural beliefs and } \\
\text { practices in agricultural } \\
\text { production }\end{array}$ & -0.40 & -0.29 & -0.41 & -0.26 & 0.05 \\
\hline TOTAL SCORE & -0.25 & -0.73 & -0.67 & -0.54 & -0.26 \\
\hline MEAN SCORE & --0.125 & -0.36 & -0.33 & -0.27 & -0.13 \\
\hline
\end{tabular}

The adoption of contour farming, particularly the establishment contour hedgerows has served as a mechanism to practice the "bayanihan" system in the three CFV sites. To encourage each farmer to adopt and establish contour farms, members of the CFV Farmers' Association were mobilized to help each one establish the contour. 


\section{Political capital}

The capacity of the community to formulate and execute laws and policies in the community; influence the higher level of government; and, maintain order in the community defines its political capital. The upland farming communities are governed by the barangay local government unit. This political unit has the authority to formulate and execute policies within the community. These laws and policies, however, have to be consistent with the laws and policies that are being implemented at the municipal local government unit, except in special cases when a specific policy is necessary to a particular barangay or village.

Results show that pathways 'monocropping in contour' and 'multiple cropping in contour' have high levels of political capital having mean scores of 0.83 and 0.79 , respectively. Meanwhile, the rest of the pathways have contributed low level of political capitals having mean score of $0.47,0.20$ and 0.41 (Table 10). The results, however, may not be brought about by the development pathways, but the conditions of the study sites, instead. Table 10 highlights that La Libertad, which has the most number of farmers adopting the 'agroforestry' pathways had the highest level of political capital, while Alfonso Lista which has a number of farmers engaged in 'agroforestry and non-farm activities' had the lowest level of political capital because of the absence of local policies and programs that are currently existing in the community.

Table 10. Mean scores of political capital indicators of farmers engaged in different development pathways

\begin{tabular}{cccccc}
\hline \multirow{2}{*}{$\begin{array}{c}\text { INDICATORS OF } \\
\text { POLITICAL CAPITAL }\end{array}$} & $\begin{array}{c}\text { Monocropp } \\
\text { ing in } \\
\text { contour }\end{array}$ & $\begin{array}{c}\text { Multiple } \\
\text { cropping in } \\
\text { contour }\end{array}$ & Agroforestry & $\begin{array}{c}\text { Agroforestry } \\
\text { and non-farm } \\
\text { activities }\end{array}$ & $\begin{array}{c}\text { Multiple cropping } \\
\text { or monocropping } \\
\text { without contour }\end{array}$ \\
\hline $\begin{array}{l}\text { Existing local policies and } \\
\text { laws related to peace and } \\
\text { order, agriculture and } \\
\text { conservation farming }\end{array}$ & 0.80 & 0.81 & 0.57 & 0.35 & 0.50 \\
\hline $\begin{array}{l}\text { Existing local programs } \\
\text { and activities related to } \\
\text { conservation farming }\end{array}$ & 0.86 & 0.78 & 0.38 & 0.06 & 0.33 \\
\hline TOTAL SCORE & 1.66 & 1.59 & 0.95 & 0.41 & 0.83 \\
\hline MEAN SCORE & $\mathbf{0 . 8 3}$ & $\mathbf{0 . 7 9}$ & $\mathbf{0 . 4 7}$ & $\mathbf{0 . 2 0}$ & $\mathbf{0 . 4 1}$ \\
\hline
\end{tabular}

The development pathways across sites have provided significant contribution to the institution of local policies and laws related to agriculture and conservation farming with a mean score of 0.57 . This is indicated by the number of local policies and laws that have been executed in line with agriculture and conservation farming as discussed earlier. The implementation of policies such as no cutting of trees; prohibition of stray animals in the cropped areas; and, intensification of contour farming promotion was an indicator that the local officials at the barangay level, and the officials of the farmers' associations have the capacity to institute laws and policies.

At the community level, however, Table 11 emphasizes that Ligao City and La Libertad have almost the same level of sustainability based on the mean scores of each of the seven capitals. This could be explained by the institutional mechanisms employed in the two communities after the termination of the CFV program in 2011. As discussed earlier, the respective local government units of the two communities have sustained the capacity-building activities and technical support program, which 
are aligned with the CFV program. For instance, in Ligao City, the local government has appointed three farmer-volunteers as CFV Coordinators whose primary responsibility is to monitor the farmer-adoptors and potential adoptors of contour farming. Since the farmer-volunteers have been the focus of the CFV training programs in the past, they have also been re-echoing to the other farmers, the knowledge and skills that they have acquired from these training. On-site training programs have also been continuously organized through the City Environment and Natural Resources Office, to sustain the knowledge sharing among the farmer-adoptors.

The local government has also executed a policy which calls for the adoption of contour farming in all the farming communities with sloping and steep farmlands. The policy was launched by the City Environment and Natural Resources Office and the Department of Social Welfare and Development through the 4Ps program. This policy has contributed to the sustained establishment of contour hedgerows.

Table 11. Mean scores of the seven community capitals of the three study sites

\begin{tabular}{lccc}
\hline \multicolumn{1}{c}{ COMMUNITY } & \multicolumn{3}{c}{ STUDY SITES } \\
\cline { 2 - 4 } \multicolumn{1}{c}{ CAPITALS } & Ligao City & Alfonso Lista & La Libertad \\
\hline Social & 0.73 & 1.00 & 1.00 \\
Human & 0.45 & 0.47 & 0.60 \\
Natural & 0.28 & 0.35 & 0.51 \\
Financial & 0.10 & 0.31 & 0.23 \\
Physical & 0.19 & 0.30 & 0.23 \\
Political & 0.67 & -0.50 & 0.93 \\
Cultural & 0.10 & -0.69 & -0.13 \\
TOTAL & 3.42 & 1.21 & 3.38 \\
AVERAGE & $\mathbf{0 . 4 9}$ & $\mathbf{0 . 1 7}$ & $\mathbf{0 . 4 8}$ \\
\hline
\end{tabular}

In La Libertad, on the other hand, the launching of the Our Food Program in 2011 was also in line with the CFV approaches. This program focuses on capacity-building, farm development, marketing of agricultural products, and cross-farm visits. This program was integrated in the Annual Investment Plan of the municipality, and thus, regular budget is allocated for the implementation of these priority programs. The agricultural technicians of the local government unit have been conducting field visits to farmer-adoptors to monitor their agroforestry farm development activities. Recognizing the poor road conditions in the upland barangays of the municipality, the local government has likewise provided transportation facilities to facilitate the efficient marketing of the agricultural products. Seeds and planting materials of hedgerow species such as flemengia, calliandra and kakawate have been provided to ensure the continuous establishment of contour hedgerows.

In the case of Alfonso Lista, however, there was no turn-over of the CFV program to any local institution, particularly the local government unit. Thus, after the CFV program in 2011, the farmer-adoptors operated on their own. Little technical assistance has been provided by the local development organizations. As cited by the key informants, "we have not been visited and monitored either by the local government unit or the faculty members from the state college. We would have wanted to continue our contour farming, but we would also like that someone from these agencies visit us for technical 
assistance". This remark was validated by the representative from the state college who stated that "after the CFV program, we did not have regular visit and monitoring to the project sites, because the faculty in-charge mas transferred to another campus'. The current leadership of the local government unit, through the Office of the Municipal Agriculturist emphasized that "there was no formal turn-over of the CFV program to the local government units, and therefore, the LGU was not able to sustain the programs and activities of CFV".

There were no follow-up activities and programs that were organized and implemented in the study site after 2011. These findings suggest, therefore, that the level of sustainability of the study sites could not only be an outcome of the development pathways that they have chosen. In particular, the community resources, particularly the institutional mechanisms play a vital role in enhancing their community capitals that would lead towards their sustainability.

\section{Conclusion}

The upland farming communities are generally characterized as having marginal biophysical conditions. The farms that are being cultivated by the farmers are generally rainfed, which are vulnerable to climate change and extreme weather events; with sloping/steep slopes, which are prone to soil erosion. In terms of socioeconomic characteristics, the upland farmers are smallholder farmers with small landholdings. Old and young farmers tend to become interested and engaged in agricultural production. The three study sites have existing local policies and programs that are related to agriculture and conservation, which helped facilitate their agricultural production, particularly agroforestry and conservation farming. There are five development pathways that were chosen by the upland farmers in the three study sites from 2000-2015. These are: agroforestry and non-farm activities; agroforestry; monocropping in contour; multiple cropping in contour; and, multiple cropping/ monocropping without contour. Results indicate that indeed, upland farming communities have the potential to attain their sustainability on the basis of the community capitals framework. Specifically, results revealed that the development pathways provide significant outcomes on some indicators of each of the seven capitals. These include improved knowledge and skills in upland farming and conservation practices, improved availability of market outlets, improved community relations, institution of local policies and programs in conservation farming, improved soil condition through controlled soil erosion, improved farm income, and stabilization of the community traditions. These outcomes are important contributions in enhancing the human, physical, social, political, natural, financial and cultural capitals towards the sustainability of the upland farming communities.

\section{Acknowledgment}

The authors acknowledge the Southeast Asian Regional Center for Graduate Study and Research in Agriculture (SEARCA) for providing the funding support to carry out this research.

\section{References}

Bass S.B, D. Clayton and J. Pretty. (1995). Participation in Strategies for Sustainable Development. Environmental Planning Issues, No. 7, 1995. Retrieved from www.pubs.iied.org/pdfs/7754IIED.pdf

Bhandari, P.B. (2013). Rural Livelihood Change? Household Capital, Community Resources and Livelihood Transition. Journal of Rural Studies 32:126-136. 
Brundtland Commission Report. (1987). Sustainable Development: Concept and Action. In: World Commission on Environment and Development. Retrieved from www.unece.org on March 15, 2015.

Chambers, R. and G. Conway. (1991). Sustainable Rural Livelihoods: Practical Concepts for the 21 ${ }^{\text {st }}$ Century. IDS Discussion Paper 296. Retrieved from www.ids.ac.uk/files/Dp296.pdf. Accessed on June 20, 2014.

Claridge T. (2004), Social Capital and Natural Resources Management. An Important Role for Social Capital? Unpublished Thesis. University of Queensland, Brisbane Australia.

Cochrane, P. (2006). Exploring Cultural Capital and its Importance in Sustainable Development. Ecological Economics 57: 318-330.

Conservation Farming Village. (2011). Project Accomplishment Report. CFV Project Team. College of Forestry and Natural Resources, University of the Philippines Los Banos, College, Laguna.

Cramb, R.A. (2004). The Role of Social Capital in the Promotion of Conservation Farming: The Case of Landcare in the Southern Philippines. ISCO 2004 - 13th International Soil Conservation Organization Conference - Brisbane, July 2004 Conserving Soil and Water for Society: Sharing Solutions. Paper No. 206.

De Janvry, A. and E. Sadoulet. (2001). Income Strategies among Rural Households in Mexico: The Role of Off-farm Activities. World Development 29 (3):467-480.

Department for International Development. (2000). DFID Guidance Sheets. In: http://www.efls.ca/webresources/DFID_Sustainable_livelihoods_guidance_sheet.pdf

Ellis, F. (2000). The Determinants of Rural Livelihood Diversification in Developing Countries. Journal of Agricultural Economics 5: 2. Retrieved from: www.researchgate.et/publication/23690437_The_Determinants_of_Rural_Livelihood_in Developing_Countries.Accessed on July 1, 2015.

Flora, J. and C. Flora. (2008). Community Capitals Framework. Retrieved from www.soc.iiassade.edu/staff/cflora/ncrcd/capitals.html

Garrity, D., Kummer, D. and Guiang, E. 1993. The Upland Ecosystem in the Philippines: Alternatives for Sustainable Farming and Forestry. National Academy Press, Washington DC. In Lasco, RD, FB Pulhin, LA Bugayong and MD Mendoza. (2011). An Assessment of Potential Benefits to Smallhoders of REDD+ Components in the Philippines. Annals of Tropical Research, 33(1):31-48. Retrieved from: http://citeseerx.ist.psu.edu/viewdoc/download?doi=10.1.1. 650.9950\&rep=rep1\&type $=$ pdf $($ accessed on March 16, 2016)

Gutierrez, J. (2013). Filipino Farmers: A Dying Breed? IRIN. Inside Stories on Emergencies. Retrieved from: http://www.irinnews.org/report/97550/filipino-farmersdying-breed

Jacobs, C. (2011). Community Capital: Cultural Capital. Extension Extra. SDSU College of Agriculture and Biological Sciences. USDA. In: http://pubstorage.sdstate.edu/agbio_publications/articles/exex16007.pdf. Accessed on January 25, 2016.

Landicho, L.D., R.G. Visco, R.D. Cabahug, R.F. Paelmo, R.S. Baliton, M.L.O. Espaldon and R.D. Lasco (2015). Field-level Evidences of Climate Change and Coping Strategies of Smallholder Farmers in Molawin-Dampalit Sub-Watershed, Makiling Forest Reserve, Laguna, Philippines. Asian Journal of Agriculture and Development (AJAD). SEARCA. Volume 2 (12).

Mercado, A.R., M. Patindol and D.P. Garrity (2000). The Landcare Experience in the Philippines: Technical and Institutional Innovations for Conservation Farming. Paper presented during the International Landcare Conference held at Melbourne, 
Australia on March 2000. In: http://www.worldagroforestry.org/downloads/ Publications/PDFS/pp04120.pdf. Accessed on February 21, 2016.

Pender, J. (2004). Development Pathways for Hillsides and Highlights: Some Lessons from Central America and East Africa. Food Policy 29: 339-367.

Pillai, A. (2010). Sustainable Rural Communities? A Legal Perspective on the Community Right to Buy. Land Use Policy 27: 898-905.

Rola, A. C. (2011). An Upland Community in Transition: Institutional Innovations for Sustainable Development in Rural Philippines. ISEAS Publishing, Singapore.

Scoones, I. (1998). Sustainable Rural Livelihoods: A Framework for Analysis. IDS Working Paper 72. In: http://www.sarpn.org/documents/d0001493/P1833-Sustainablerural-livelihoods_IDS-paper72.pdf. Accessed on June 2, 2014.

Tolentino, L.L., L.D. Landicho, K. Ikegami and S. Wungaeo. (2012). Emerging Trends of Rural Sociology in Asia. Paper presented during the International Congress of International Rural Sociology Association (IRSA), July 30-August 1, 2012, Portugal.

United Nations Commission on Environment and Development. (1992). Rio Declaration on Environment and Development. Retrieved from http:/www.unesco.org/education/nfsunesco/pdf/RIO_E.pdf. Accessed on May 13, 2015.

World Development Report. (2008). Rural Households and Their Pathways Out of Poverty. World Bank. In: http://siteresources.worldbank.org/INTWDR2008/ Resources/2795087-1192112387976/WDR08_06_ch03.pdf 